\title{
AN ANALYSIS OF DIRECTIVE ILLOCUTIONARY ACTS IN THE COMPLEX: LOCKDOWN 2020 MOVIE
}

\author{
Ni Made Putri Sugiantini' ${ }^{1}$ Putu Devi Maharani², IB Gde Nova \\ Winartha, ${ }^{3}$ \\ Mahasaraswati Denpasar University, Indonesia ${ }^{123}$ \\ putrisugiantinii@gmail.com,_devmaharani86@gmail.com, \\ gusdnova@gmail.com
}

\begin{tabular}{|c|c|}
\hline & ABSTRACT \\
\hline Journal History & $\begin{array}{l}\text { This goal of this study is to describe the types of } \\
\text { directive illocutionary act and to find out the most }\end{array}$ \\
\hline Submitted 14 $4^{\text {th }}$ January 2021 & characters in The Complex: Lockdown movie \\
\hline Revised 9th March 2021 & through the theory of Speech Act by Kreidler (1998) \\
\hline Accepted 20th April 2021 & and supported by the theory from Searle (1979). In \\
\hline Published 29th July 2021 & analyzing the data, descriptive qualitative method is \\
\hline & $\begin{array}{l}\text { used. This study found } 73 \text { data of directive } \\
\text { illocutionary act performed by the characters in the }\end{array}$ \\
\hline & $\begin{array}{l}\text { movie. In addition, it was found the most dominant } \\
\text { directives used is command with } 27 \text { (37\%) }\end{array}$ \\
\hline Keywords: & $\begin{array}{l}\text { occurences followed by question with } 23(32 \%) \\
\text { occurences. Both types of directive is the most }\end{array}$ \\
\hline Illocutionary Act, Directive & $\begin{array}{l}\text { commonly used because the characters are forced to } \\
\text { do a certain task quickly with a limited time to }\end{array}$ \\
\hline Illocutionary Act, Movie & think. That causes they gave command to other and \\
\hline & $\begin{array}{l}\text { asked question frequently during the emergency } \\
\text { situation after several bio-weapon attacks. The least }\end{array}$ \\
\hline & $\begin{array}{l}\text { dominant types of directive speech act are found } \\
\text { namely; request with } 16(22 \%) \text { occurences and } \\
\text { followed by suggestion with } 7(9 \%) \text { occurences. }\end{array}$ \\
\hline
\end{tabular}

INTRODUCTION

According to Pearson, J., \& Nelson, P. (2000), communication is a process of understanding and sharing of meaning. When people communicate with others, they need to know how to ask a question, give a suggestion, offer an apology, greet, request, complain, invite, and refuse. In addition, When people communicate with other, they produce an utterance, Norca (2019). People can express their feelings by producing 
some words to others. Through their utterance people can directly deliver their message. Even though using utterances is more efficient, people tend to use utterances with implied meaning in their life communication. Those utterances are aimed to cause a certain effect to the hearer and also can perform an action. Yule (1996) believes that when someone is producing an utterance, that person not only utters something but also acts. An utterance that produces a performative action is called speech act.

Austin (1962) defined speech acts as the actions performed when an utterance is produced. Speech act is as an act that is performed through an utterance produced by a speaker. According Austin in Yule (1996:48) there are three categories of speech acts, which are namely Locutionary, Illocutionary and Perlocutionary acts. Locutionary Act refers to what is actually being said by a speaker, Illocutionary Act refers to what is being accomplished through the speaker's utterance and Perlocutionary Act refers to what is the effect of the utterance to hearer. However, in daily conversation, illocutionary acts are the most common speech act that are used to perform an action to cause effect to the hearer. Furthermore, one type of Illocutionary act that is commonly performed is Directives.

Directives is an illocutionary act that performed in order for the hearer to do something. According to Kreideler (1998: 190) directive utterances are those in which the speaker tries to make the adresse or the hearer to perform some acts or refrain from perform an act. Searle (1979) in Leech (1993:64) also explained the directive speech act is the type of illocutionary act that aims to produce an effect in the form of the action taken by the hearer. To put simply, speakers tend to indirectly tells the hearers to do a certain action through their utterances. Furthermore, Kreidler (1998: 190-191) classifies directives into three kinds, namely commands, requests, and suggestions. In addition, Searle (1979:14) also believes that questions are also included as directive speech act since they are attemps by the speaker to get the hearer to anwer, hence performing speech acts. Based on that explanation, the current study is focused on analyzing several type of directives which are namely: (i) command, (ii) request, (iii) suggestion and (iv) question. Command can be defined as an act by someone who has an authority giving an obligation to the other person which usually in the imperative form. Request is an expression of what the speaker wishes the hearer to do or refrain from doing something which usually shown in more polite manner. A request does not presume the power of the speaker over the person addressed. Suggestion are the statements made to other people to offer our thoughts about what they should do or not do. Finally, Question is an expression by the speaker in order to obtain a certain answer from the hearer.

The data source of this research is a movie. According to Cambridge University Press Dictionary (2019) movie also known as film, is type of 
visual communication which uses moving pictures and sound to tell stories or informs people what is in the story about. There are a lot of speech acts are that usually put in the movie to make the movie more interesting to watch. More variety of languages are used in the movie that make the people who watch it exited and want to watch the movie again. In this study, the data source is the movie The Complex: Lockdown 2020, which chosen because in the dialogues and script of the movie contain a lot of utterances that can be categorized as illocutionary act, especially directive illocutionary act. Therefore in order to know when a speaker performs an act in their utterance, the analysis of directive illocutionary act is conducted with The Complex: Lockdown 2020 movie chosen to be the data source.

\section{METHODS}

In this study, The complex: Lockdown movie was used as a data source. Spesifically, the data was taken from the utterance of characters in the movie. The data were collected using observation method that is by watching the movie of The Complex: Lockdown 2020 repeatedly to find out and understand every utterances that uttered by the characters in the movie. The data were classified into types of directive illocutionary act such as: command, request, suggestion and question. The data then analyzed through qualitative method according to the theory of Speech Act from Kreidler (1998) and supported by the theory from Searle (1979) in order to describe the types of directive performed by the characters in the movie. Finally, the data that obtained from the The Complex: Lockdown 2020 movie were presented by using both, formal and informal method.

\section{RESULTS AND DISCUSSION}

\section{RESULT}

The finding of this study the occurence of directive illocutionary act that has been divided into several type of directives.

Table 1. Types of Directive Illocutionary Act Found in The Complex: Lockdown 2020 Movie

\begin{tabular}{|c|c|c|}
\hline $\begin{array}{l}\text { Types of Directive } \\
\text { Illocutionary Act }\end{array}$ & Frequency & Percentage \\
\hline Command & 27 & $37 \%$ \\
\hline Request & 16 & $22 \%$ \\
\hline Suggestion & 7 & $9 \%$ \\
\hline Question & 23 & $32 \%$ \\
\hline Total & 73 & $100 \%$ \\
\hline
\end{tabular}


The finding of this study has shown that there are 73 data regarding to directive illocutionary act perfomed by the characters in the movie. The most dominant type is shown to be command with $27(37 \%)$ occurences followed by question with $23(32 \%)$ occurences. Those dominant type shows that the emergency situation during the aftermath of several bioweapon attacks forces them to always move in quick pace and also with a limited amount of time to think which makes them tend to ask other person to do something and also asking question more often. The least dominant types of directive in the movie is request with $16(22 \%)$ occurences which shown by asking someone to do something in more polite manner and finally, suggestion 7 (9\%) occurences in which occured when the characters are giving their opinion or thoughts to the other. In requesting, the characters tend to ask someone to do something more politely rather than added their power to the utterance. While in suggesting, the characters in the movie share their thoughts or opinion about something to the other character without any forcing their decision whether do accept or deny it.

\section{Discussion}

All types of directive illocutionary act along with the function are explained in the following section. Several data that have been selected as the example is presented in the discussion.

\section{Types of Directive Illocutionary Act in The Complex: Lockdown 2020 Movie.}

\section{A. Command}

The most dominant type of directive illocutionary act found in this study is command with $27(37 \%)$ occurences among 74 data. Command is defined as giving a strong order which usually performed by someone who has an authority. Several example regarding to this type of directive is provided as follows.

\section{Data 1}

Dr. North : What shall we do, Doctor?

Amy : Set up for full blood diagnostic. There has be a way to get the nanocells out of her safely.

\section{$(00: 21: 57-00: 22: 07)$}

The context of the dialogue above is when Dr. Amy Tenent is faced with a case of a young girl named Clare Mahek who have been infected with some type of diseases. In the beginning, Clare was suspected to be a terrorist who intentionally spread a virus to many people which also referred as bio-weapon. After a video of Clare collapsing has gone viral, she 
was brought to the lab of Kensington company in which Dr. Amy worked in. Then, several test was conducted to Clare and later, it is found that the nanocells developed by Dr. Amy has been injected to her blood stream unknowingly. The head of the Kensington company, Nathalie then insturcted Dr. Amy and her team to retrieve the nanocells as the top priority without considering Clare's life might be in danger. After hearing the instruction, Dr. North who is one of the lab's assitant asked for Dr. Amy's next intruction. As a person in charge of the case and the lab, Dr. Amy commanded her to set up full blood diagnostic and find a way to retrieve the nanocells out of Clare's body safely without risking her life.

The utterance of Dr. Amy is considered as directive illocutionary act because there is an act performed through the speaker's utterance in which asking someone to do something. The type of directive used in the utterance is shown to be a command because it is a strong order given by someone who has higher authority. Dr. Amy's position as the person in charge of the lab and also the case gives her the power command other person to do a certain task. The type of the sentence which is imperative sentence also supported the fact that the utterance is considered as command.

\section{Data 2}

Dr. Wakefield : I'm good, check on Dr. North.

(00:25:06-00:25:08)

The utterance is produced by Dr. Wakefield in the Kensington's laboratory, the place where Dr. Amy worked in. The context of the situation is during one of Dr. Amy's lab assitant named Dr. Malkins turned against them and tried to harm Dr. Amy. Prior to the utterance, Dr. Malkins asked Dr. North to open a crate containing poison which originally aimed for Dr. Amy. As a terrorist who ordered to harm Dr. Amy, Dr. Malkins brough the crate to the lab and hoping for Dr. Amy to open it. Unfortunately, Dr. North unknowingly opened the crate and inhaled the deadly poison. Dr. Malkins then directly tried to attack Dr. Amy and pull out a knife intending to stab her. Dr. Wakefield then, directly tried to help her by smashing Dr. Malkins head. They both ended up fighting and Dr. Wakefield was stabbed at the knees. Dr. Amy who say him getting stabbed approached him and offered to help. Dr. Wakefield then, refused by saying "I'm good, check on Dr. North" referring to Dr. North condition that is worse than him because of the poison.

The utterance of Dr. Wakefield above is considered as directive illocutionary act because it is telling someone to do a certain action. Furthermore, it is can be categorized as command because the statement is uttered with a strong order by someone with an authority. In this case, Dr. 
Wakefield has an authority to give an order to Dr. Amy because he is in an equal position as Dr. Amy at the moment and also had stated that he is alright therefore he ordered Dr. Amy to help Dr.North instead. The sense of emergency also forced Dr. Wakefield to command Dr. Amy to check on the other person who need more help than him.

\section{B. Question}

The second most dominant type of directive used in the movie is question. There are 23 data that can be defined as question in the movie. According to Searle (1979), question is also considered as directives because there is an act performed by the speaker in attemps to get an answer by the hearer. Several data that is considered as question is provided below.

Data 3

\section{Dr. Wakefield : Look, have we considered the hysteria might actually be valid?}

(00:12:27-00:12:30)

The context of the utterance is when Dr. Wakefield was during a conversation with Dr. Amy and Nathalie, the leader of the Kensington company. Previously, Dr. Amy who was presenting a material in front of the company's investor was urgently needed by Nathalie. It turned out related with the case of the video that has gone viral about a young company;s intern collapsing in a train. Dr. Amy then directly meet with Nathalie in the lobby and later, followed by Dr. Wakefield. Dr. Amy and him turned out to be a partner during the virus outbreak in Kindar, a village in Asia but, Dr. Wakefield left Dr. Amy because of a certain reason. From their meeting after a long time, it can be concluded that Nathalie not only asking for Dr. Amy's help but also Dr. Wakefield expertise to handle with the case. During their way to the laboratory, Dr. Wakefield who liked to talk too much, asked to Nathalie and Dr. Amy whether the hysteria regarding the bio-weapon terrorist attack was true in the first place

The statement of Dr. Wakefield is included as directive illocutionary act because there is an action performed in the utterance that is telling someone to do something. The type of directive of the utterance is question that is shown by the act of the speaker demanding an answer from the hearer. By asking a question, the speaker attemps to get the answer from the hearer. In this case, Dr. Wakefield asked for the truth regarding to the rumour of terrorist attack that had spread in London at the time and demanded a related answer from Nathalie and Dr. Amy. 
Data 4

Clare $\quad$ : I'm not an espionage mastermind. They aren't with me.

Amy

: So how did all the nanocells end up inside you?

(00:35:38-00:35:39)

The conversation occured between Dr. Amy Tenent and Clare in the Kensington laboratory. It is occured right after Dr. Reese Wakefield was hacking on the camera in Nathalie and intended to spy on her. It was found that there was a traitor that sabotage the nanocells and injected it to Clare. The situation during the time of terrorists infiltrating the lab forced Dr. Amy and Dr. Wakefield to think more deeply about the truly happened. Dr. Wakefield then encourage Dr. Amy to ask Clare about the traitors mentioned by Nathalie previously. After approaching Clare, Amy asked about her real identity and Clare replied that she was not the person Amy was thinking about. Clare stated that she was not a part of terrorists that have been attacking them. Dr. Amy then, wonder about the way that the nanocells end up in her body by saying "So how did all the nanocells end up inside you?".

The utterance of Amy in the dialogue is included as directive illocutionary act because it is performing an act that telling someone to do a certain act. The type of directive used in the utterance is question because according to Searley (1979), questions is included as directives because the speaker attempts to get an answer from the hearer. In the dialogue, Dr. Amy who wondered about the traitor and the way of her nanocells to be ended up in Clare's body attempted to get an answer from Clare regarding to the truth and hoping that she would get the spesific answer that can help her through the situation.

\section{Request}

Request becomes the third rank in the number of occurences that can be found in the movie. The number of data that is considered as request are 16 data. In requesting, people tend to ask someone to do something or refrain of doing something in more polite manner rather than giving commands. The example of data analysis regarding to this type is provided below.

Data 5

Clare $\quad:$ I did this for Mina. 
Dr. North : What's Mina?

Dr. Wakefield : A terrorist organization.

Amy : Oh, will you stop that, please?

(00:20:43-00:20:45)

The dialogue is performed by Dr. Amy Tenent, Dr. Everly North, Dr. Reese Wakefield and Clare Mahek in the Kensington's Laboratory. In the dialogue, Dr. Amy and her team were discussing the case in which a young girl named Clare was brought to the facility because of being infected by some infectious diseases and injected with nanocells. Because of the recent incident of bio-weapon attack, Dr. Wakefield asked her whether she was part of a terrorist member. Clare replied that she was not but she said "I did this for Mina". Dr. North who is confused directly asked them "What is Mina?" referring to the name that mentioned by Clare. Dr. Wakefield than, blatantly answered that Mina was the name of a terrorist organization. Dr. Amy who was not really sure if Clare was related with the attack and felt enough of hearing those kind of talk, requested Dr. Wakefield by saying "Oh, will you stop that please? Intending to make him to stop accusing Clare of being a terrorist without any strong evidence.

Dr. Amy's utterance in the dialogue is considered as directive illocutionary act because there is an action performed in the utterance that is to tell someone to do something. Furthermore, the type of directive used in Dr. Amy's utterance is request because the speaker wishes the hearer to refrain of doing something which in this case, Dr. Amy requested Dr. Wakefield to stop referring Clare as a part of terrorist member. Even there are many incidents related with bio-terrorist attack previously, without any strong evidence they cannot accusing Clare of being a terrorist. Therefore, through her utterance, Dr. Amy politely refrains Dr. Wakefield of accusing Clare further without any strong evidence.

Data 6

Amy : Dr. Wakefield, can you move this crate, please?

(00:23:33-00:23:37)

The context of the utterance is when Dr. Amy Tenent was in the Kensington's laboratory while handling the case of Clare Mahek, a girl accused of being a bio-terrorist. Previously, Dr. Amy instructed her team to find a solution in order to remove the nanocells out of Clare's body without risking her life. Soon after that, she walked to a counter to find a large crate there, blocking her working space. Even on the crate there was a letter 
saying that it was meant for her, she intended to open it later and asked Dr. Wakefield to move it for her. He was being the one asked because aside of being close with her, he was the one that available during the time. Dr. Amy then, called his name loudly and asked him to move the crate by saying, "Dr. Wakefield, can you move this crate, please?".

The utterance is considered as a directive illocutionary act because it is telling someone to do a certain action which in this case, Dr. Amy asked Dr. Wakefield to move the crate that was blocking her working space. Spesifically, the utterance is categorized as a request because the speaker asked someone to do something but in more polite manner than giving a command. In request, the hearer is given the time to consider whether to do it or not. In her utterance, Dr. Amy is not using her authority as the person in charge of the lab but instead asking Dr. Wakefield a favor as a long time friend. Because of that explanation, the type of directive of Dr. Amy's utterance is categorized as request.

\section{Suggestion}

The least dominant type in the number of occurences in the movie is suggestion with 7 occurences among 74 data. Suggestion is occured when the speakers offer their thoguhts to the hearer. Several data as examples are provided as follow.

Data 11

Amy : No, I suggest you to leave it in, Clare. You need it.

(00:20:26-00:20:28)

The utterance is produced by Dr. Amy Tenent while handling a case of Clare Mahek, a girl who is accused of being a terrorist. Because of the girl collapsing went viral, Dr. Amy and her team were assigned to investigate the case and later, it was found that the cause is because nanocells developed by Dr. Amy was injected to Clare body unknowingly. Clare was brought to the Kensington's laboratory and being monitored. Dr. Amy and her team argued whether Clare was a part of terrorist that attacked several years ago who used bio-weapon. During the conversation, Clare was awake and directly trying to remove her supporting tools and her oxygen pipe. Dr. Amy who saw it prevented her of releasing herself of the tools. Dr. Amy said, "No,no, I suggest you to leave it, Clare. You need it." referring to the oxygen pipe attached to her nose.

The statement of Dr. Amy is considered as directive illocutionary act because through her utterance, she is telling someone to do something. The type of directive used in the statement is suggestion because the speaker 
gives his/ her thoughts or opinion to the hearer. In this case, Dr. Amy is suggesting Clare to keep her oxygen pipe attached to her nose because she needed it in order to survive. The statement also spesifically added with the word, 'suggest' in order to let the hearer know what the speaker is intended to say. Dr. Amy thought that Clare needed her life supporting tools such as the oxygen pipe in order to help her breathe because of the diseases caused by nanocells in her body. Therefore, by offering her thought to the hearer, the type of directive used in Dr. Amy's utterance is categorized as suggestion.

Data 12

\section{Dr. Wakefield : Amy, you need to take a minute and think about this, ok? I know a rushed decision when I see one.}

(00:48:52-00:48:54)

The dialogue is performed by Dr. Wakefield and Dr. Amy after finding the truth about their current situation and her nanocells. Prior to the dialogue, Clare was finally being open to Dr. Wakefield and Dr. Amy by telling the true story behind her act and the conspiracy of the leader of the company, Nathalie. Clare said that she injected the nanocells herself because of the company used the people from her village including her sister and parents as guinea pig for the experiment of nanocells. The experiment is the cause of the death of her family and she intended to bring the nanocells to the MI6 as the evidence of the conspiracy by injecting it to her body. After hearing the truth, both Dr. Amy and Dr. Wakefield were shocked and angry. Later, when Nathalie called from her office, Dr. Amy intended to answer the call and asked Nathalie about the truth but Dr. Wakefield prevented it. Dr. Wakefield looked Dr. Amy in the eye and saying "Amy, you need to take a minute and think about this,ok?" suggesting her to think again about her decision.

The utterance of Dr. Wakefield above is considered as directive illocutionary act, because it is telling someone to do something. Furthermore, the utterance is categorized as suggestion because the speaker offers his opinion about something to the hearer. In this case, Dr. Wakefield suggested Dr. Amy to re-think about her decision on asking to Nathalie directly after hearing the truth from Clare. In his utterance, Dr. Wakefield added that he know about a rushed decision which usually will be bad. Because of giving his opinion to Dr. Amy and suggesting her to re-think of her decision, Dr. Wakefield's utterance is categorized as suggestion. 


\section{CONCLUSION}

This study is focused on describing the types of directive illocutionary act together with finding the most dominant directive used by the characters in The Complex: Lockdown 2020 movie. The study shows the total of 73 data regarding to the directive of illocutionary act. Among those data, the most dominant type of directive performed by the characters is command with $27(37 \%)$ occurrences. The second rank of the number of occurrences is question with $23(32 \%)$ occurrences. Based on those dominant types, it can be concluded that the characters are often giving strong commands and frequently asking question to the other because they were forced by the emergency situation during the aftermath of series of bio-weapon attacks that took place in London. The situation forces them to do task quickly and carefully with the limited time to think which causing them ask question frequently. Meanwhile, the other types such as request is occurred $16(22 \%)$ times and suggestion with $7(9 \%)$ occurrences as the least dominant type of directive that can be found in the movie.

\section{REFERENCES}

Austin, J.L. 1962. How to Do Things with Words. Oxford: University Press.

Cambridge University Press Dictionary. 2019. Definition of Movie from Cambridge Academic Content Dictionary: Cambridge University Press.

Pearson, J., \& Nelson, P. (2000). An introduction to human communication: Understanding and sharing (p. 6). Boston, MA: McGraw-Hill.

Leech, G. 1983. The Principle of Pragmatics. London and New York:

Kreidler, C. W. (1998). Introducing English semantics. London: Routledge.

Searle, J.R. 1979. Expression and Meaning studies in the Theory of Speech Act. New York: Cambridge University Press

Norca, Paskalinus. G. 2019. An Analysis of Barrack Obama's Illocutionary Speech Acts at Democratic National Convection in 2012. Denpasar: English Study Program, Faculty of Foreign Languages Mahasaraswati University.

Yule, George. 1996. Pragmatics (Oxford Introduction to Language Study). New York: Oxford University Press. 